Jurnal Health Sains: p-ISSN: 2723-4339 e-ISSN: 2548-1398

Vol. 3, No. 1, Januari 2022

\title{
PERILAKU ALTRUISME PERAWAT RAWAT INAP RS ANANDA BEKASI
}

\author{
Mahmuddin, Rokiyah Kusumapradja, Idrus Jus'at
}

Universitas Esa Unggul, Jakarta, Indonesia

Email:mahmuddin.ibral@gmail.com,rokiah.kusumapradja@esaunggul.ac.id, idrus.jusat@esaunggul.ac.id

\begin{tabular}{|c|c|}
\hline INFO ARTIKEL & ABSTRAK \\
\hline $\begin{array}{l}\text { Diterima } \\
\text { 5 Januari } 2022 \\
\text { Direvisi } \\
\text { 15 Januari } 2022 \\
\text { Disetujui } \\
\text { 25 Januari 2022 } \\
\text { Kata Kunci: } \\
\text { konflik keluarga- } \\
\text { pekerjaan; burnout, } \\
\text { stres kerja; perilaku } \\
\text { caring; altruisme }\end{array}$ & $\begin{array}{l}\text { Perilaku caring merupakan spirit dari asuhan keperawatan. Penelitian ini } \\
\text { bertujuan untuk menganalisis pengaruh konflik keluarga-pekerjaan, } \\
\text { burnout dan stres kerja terhadap perilaku caring perawat wanita rawat } \\
\text { inap yang sudah berkeluarga. Manfaat penelitian untuk menurunkan } \\
\text { konflik keluarga-pekerjaan, burnout, stres kerja dan meningkatkan } \\
\text { perilaku caring perawat wanita yang sudah berkeluarga. Lokasi } \\
\text { penelitian ruang rawat inap RS Ananda Bekasi. Metode penelitian } \\
\text { kuantitatif dengan menggunakan model analisis regresi linier berganda } \\
\text { dan teknik pengumpulan data menggunakan kuesioner kemudian } \\
\text { pengujian analisis data menggunakan SPSS 25. Hasil penelitian } \\
\text { menunjukkan bahwa ada pengaruh konflik keluarga-pekerjaan dan } \\
\text { perilaku caring perawat secara negatif dan signifikan. Ada pengaruh } \\
\text { burnout dan perilaku caring perawat secara negatif dan signifikan. Ada } \\
\text { pengaruh stres kerja dan perilaku caring perawat secara negatif dan } \\
\text { signifikan. Secara simultan konflik keluarga-pekerjaan, burnout dan stres } \\
\text { kerja berpengaruh positif dan signifikan terhadap perilaku caring } \\
\text { perawat. Temuan penelitian adalah burnout dan stres kerja yang paling } \\
\text { dominan mempengaruhi perilaku caring perawat secara positif dan } \\
\text { signifikan. Perawat mengalami burnout dan stres kerja tetapi perilaku } \\
\text { caring perawat tetap tinggi terhadap pasien, sehingga dapat disimpulkan } \\
\text { bahwa perawat walaupun mengalami burnout dan stres kerja pada } \\
\text { pekerjaannya tetapi kepentingan pasien lebih diutamakan dibandingkan } \\
\text { dengan kepentingan pribadi perawat, sikap inilah yang mendorong } \\
\text { kepedulian perawat yang disebut dengan sikap altruisme yaitu perilaku } \\
\text { yang lebih mementingkan kepentingan pasien diatas kepentingan pribadi } \\
\text { perawat itu sendiri. }\end{array}$ \\
\hline
\end{tabular}

\section{ABSTRACT}

This study aimed to analyze the effect of family-work conflict, burnout and job stress on caring behavior inpatient nurses who are married. The benefits of research to reduce family-work conflict, burnout, job stress and improve nurse caring behaviors of women who are married inpatient Ananda Hospital in Bekasi. Quantitative research methods using multiple linear regression analysis model, data collection techniques using a questionnaire to test data analysis using SPSS 25. The results show that there is a relationship-work family conflict and work stress in a positive and significant. There is a relationship-work family conflict and burnout positively and significantly. There is a relationship family-work conflict and nurses caring behavior in a negative and significant. There is a relationship of work stress and nurses caring behavior in a negative and significant. There is a

$\begin{array}{ll}\text { How to cite: } & \text { Mahmuddin et.al (2022) Perilaku Altruisme Perawat Rawat Inap RS Ananda Bekasi. Jurnal Health } \\ & \text { Sains 3(1). https://doi.org/10.46799/jhs.v3i1.394 } \\ \text { E-ISSN: } & 2723-6927 \\ \text { Published by: } & \text { Ridwan Institute }\end{array}$


relationship burnout and nurses caring behavior in a negative and significant. There is the influence of family-work conflict and nurses caring behavior in a negative and significant. There is the influence of burnout and nurses caring behavior in a negative and significant. There is an effect of work stress and nurses caring behavior in a negative and significant. Simultaneously, family-work conflict, burnout and job stress positive and significant impact on the behavior of the nurses caring. There is the influence of burnout and nurses caring behavior in a negative and significant. There is an effect of work stress and nurses caring behavior in a negative and significant. Simultaneously, familywork conflict, burnout and job stress positive and significant impact on

Keywords:

family-work conflict; burnout;

job stress; caring

behavior the behavior of the nurses caring. There is the influence of burnout and nurses caring behavior in a negative and significant. There is an effect of work stress and nurses caring behavior in a negative and significant. Simultaneously, family-work conflict, burnout and job stress positive and significant impact on the behavior of the nurses caring

\section{Pendahuluan}

Perawat sebagai sumber daya manusia yang bekerja di rumah sakit dalam melaksanakan tugasnya sebagai pemberi asuhan keperawatan selalu berhubungan dengan pasien dan keluarga paien yang memiliki berbagai macam keluhan, jenis penyakit, karakter, budaya, latar belakang pendidikan dan sosial ekonomi yang berbeda. Perawat dituntut untuk lebih mampu mengatasi dan memberikan pelayanan yang berkualitas. Masalah pelayanan kesehatan di Indonesia masih dianggap sebagai pemicu timbulnya ketidakpuasan di masyarakat.

Kebanyakan perawat di Indonesia adalah wanita. Ada yang single dan ada yang sudah berkeluarga. Perawat wanita sebagai pekerja yang sudah berkeluarga sesuai dengan keadaan sosial budaya yang tumbuh dan berkembang di Indonesia selama ada tiga tugas utama wanita dalam rumah tangga yaitu: sebagai istri untuk mendampingi suami, sebagai pendidik untuk mendidik anakanaknya dan sebagai ibu rumah tangga bertugas mengurus seluruh anggota keluarga. Konflik keluarga-pekerjaan dapat muncul apabila wanita pekerja yang sudah berkeluarga merasakan ketegangan antara peran keluarga dengan peran pekerjaan, dimana disatu sisi harus memperhatikan keluarga secara utuh namun disisi lain harus bekerja sehingga waktu untuk melakukan pekerjaan di rumah sakit tersita untuk memperhatikan keluarga. Kondisi ini sering kali menimbulkan perasaan bersalah dan tekanan pada perawat wanita yang sudah berkeluarga.

Pelayanan keperawatan di laksanakan selama 24 jam, tenaga perawat memegang peran penting dalam memberikan pelayanan keperawatan dan perawat yang paling lama bertemu dengan pasien dan keluarganya. Didalam keperawatan perilaku caring merupakan hal yang paling penting untuk semua perawat. Caring adalah perhatian perawat dengan sepenuh hati terhadap pasien, sabar, tulus, empati, komunikasi yang lemah lembut. Rasa kasih sayang perawat terhadap pasien akan membentuk hubungan yang terapeutik. Dengan demikian pasien merasa nyaman, aman dan rasa stress akibat penyakit yang diderita menjadi berkurang sehingga kepuasan pasien dapat diwujudkan. Akan tetapi pada kenyataannya masih ada perawat yang belum berperilaku caring pada pasien dan keluarganya.

Berdasarkan hasil survey kepuasaan pasien yang dilakukan oleh Depkes RI pada beberapa rumah sakit dijakarta menunjukkan bahwa $14 \%$ pasien tidak puas terhadap pelayanan kesehatan yang diberikan, disebabkan karena perilaku caring kurang 
baik (Depkes, 2008). Hasil Survey penelitian pada bulan Juli 2010, hasil survey Citizen Report Card (CRC) yang mengambil sampel pasien rawat inap sebanyak 738 pasien di 23 Rumah Sakit (Umum dan Swasta). Survey tersebut dilakukan di lima kota besar di Indonesia dan ditemukan 9 poin permasalahan, salah satunya adalah sebanyak $65,4 \%$ pasien mengeluh terhadap sikap perawat yang kurang ramah, kurang simpatik dan jarang tersenyum.

Sedangkan menurut Kan dan $\mathrm{Yu}$ (2016) dalam penelitiannya menemukannya bahwa karyawan yang mengalami konflik peran ganda lebih banyak menghabiskan waktu dan tenaga untuk menyelesaikan tanggung jawab yang berhubungan dengan keluarga yang membuat mereka lebih lelah secara fisik. Tanggung jawab pekerjaan seringkali berhimpitan dengan tanggung jawab keluarga dan begitupun sebaliknya. Ketika konflik terjadi, sulit bagi individu untuk menyelesaikan tug as yang berhubungan dengan dua domain tersebut. (Phillips, 1993) membuktikan bahwa konflik peran ganda merupakan salah satu penyebab stres. Mereka menemukan interaksi antara tugas rumah dan kantor merupakan pemicu stres yang tinggi pada wanita bekerja.

Masalah konflik pekerjaan keluarga, burnout dan stres kerja pada perawat wanita perlu mendapatkan perhatian serius karena hal ini akan berpengaruh terhadap perilaku caring dan kinerja perawat dalam memberikan pelayanan. Apabila stres kerja perawat tinggi maka kinerja perawat menjadi rendah dan secara otomatis dapat menurunkan kualitas dan produktivitas kerja rumah sakit secara keseluruhan yang nantinya akan berdampak pada penurunan pendapatan rumah sakit. Hal ini terjadi karena minat masyarakat untuk memilih rumah sakit tersebut sebagai tempat mereka berobat menjadi menurun karena pelayanan yang diberikan tidak memuaskan.
Berdasarkan latar belakang tersebut diatas peneliti tertarik melakukan penelitian untuk mengetahui lebih lanjut seberapa besar pengaruh konflik pekerjaan-keluarga, burnout serta stres kerja terhadap perilaku caring perawat di ruang rawat inap yang sudah berkeluarga di Rumah Sakit Ananda Bekasi.

Untuk menganalisis pengaruh konflik keleuarga-pekerjaan, burnout dan stres kerja terhadap perilaku caring perawat wanita sudah berkeluarga rawat inap.

\section{Metode Penelitian}

Penelitian ini menggunakan penelitian kuantitatif komparatif dengan model analisis regresi linier berganda. Penelitian komparatif yaitu penelitian yang diarahkan untuk menyelidiki hubungan sebab-akibat berdasarkan pengamatan terhadap akibat yang terjadi dan mencari faktor yang menjadi penyebab melalui data yang dikumpulkan. Sedangkan analisis regresi linier berganda adalah hubungan secara linear antara dua atau lebih variabel independen dengan variabel dependen. Analisis ini untuk mengetahui arah hubungan antara variabel independen dengan variabel dependen apakah masing-masing variabel independen berhubungan positif atau negatif.

Pengumpulan data menggunakan pendekatan medote survai dan teknik korelasional, variabel dependen adalah perilaku caring perawat (Y), dan variabel independen adalah konflik keluarga-pekerjaan (X1), burnout (X2), stres kerja (X3). Metode pengukuran penelitian ini menggunakan pengukuran melalui metode skala likert. Data yang digunakan dalam penelitian ini adalah data primer. Populasi dalam penelitian ini adalah perawat wanita yang sudah berkeluarga instalasi rawat inap Rumah Sakit Ananda Bekasi.

Pelayanan Instalasi Rawat Inap Rumah Sakit Ananda terdiri atas ruang perawatan cendana untuk perawatan kebidanan, ruang perawatan cemara untuk perawatan pasien 
umum dewasa, ruang perawatan sakura untuk perawatan anak dan dewasa, ruang perawatan flamboyan untuk perawatan pasien BPJS, ruang perawatan perinatologi yang terbagi Level 1-3 dan ruang perawatan intensive (ICU dan HCU). Sampel dalam penelitian ini adalah semua perawat wanita yang sudah berkeluarga instalasi rawat inap Rumah Sakit Ananda Bekasi. Jumlah sampel dalam penelitian ini sebanyak 73 responden yang diambil dengan teknik sampling.

a. Deksripsi Karakteristik Responden

\section{Hasil dan Pembahasan}

\section{Tabel 1}

Distribusi Berdasarkan Karakteristik Responden

\begin{tabular}{|c|c|c|c|}
\hline No & Usia & Jumlah & Persentase \\
\hline \multirow[t]{6}{*}{1} & Usia Responden & & \\
\hline & a. $20-24$ Tahun & 6 Orang & $8,2 \%$ \\
\hline & b. $25-29$ Tahun & 17 Orang & $23,3 \%$ \\
\hline & c. $30-34$ Tahun & 31 Orang & $42,5 \%$ \\
\hline & d. $35-39$ Tahun & 14 Orang & $19,2 \%$ \\
\hline & e. $40-44$ Tahun & 5 orang & $6,8 \%$ \\
\hline \multirow[t]{3}{*}{2.} & Pendidikan & & \\
\hline & a. D3Keperawatan & 68 Orang & $93,2 \%$ \\
\hline & b. S1 Keperawatan & 5 Orang & $6,8 \%$ \\
\hline \multirow[t]{6}{*}{3.} & Lama Bekerja & & \\
\hline & a. 1-5 Tahun & 26 Orang & $35,6 \%$ \\
\hline & b. $6-10$ Tahun & 25 Orang & $34,2 \%$ \\
\hline & c. $11-15$ Tahun & 14 Orang & $19,2 \%$ \\
\hline & d. $16-20$ Tahun & 7 Orang & $9,6 \%$ \\
\hline & e. $21-25$ Tahun & 1 Orang & $1,4 \%$ \\
\hline \multirow[t]{3}{*}{4.} & Status Kepegawaian & & \\
\hline & a. Pegawai & 60 Orang & $82,2 \%$ \\
\hline & b. Honorer & 13 Orang & $17,8 \%$ \\
\hline \multirow[t]{5}{*}{5.} & Jumlah anak & & \\
\hline & a. 1 Anak & 40 Respoden & $34,2 \%$ \\
\hline & b. 2 Anak & 58 Respoden & $49,6 \%$ \\
\hline & c. 3 Anak & 15 Respoden & $12,8 \%$ \\
\hline & d. 4 Anak & 4 Respoden & $3,4 \%$ \\
\hline
\end{tabular}

Sumber: Hasil Pengolahan Data Primer, 2020

Berdasarkan tabel 1 karakteristik responden dapat disimpulkan bahwa karakteristik usia responden paling banyak berusia antara 30-34 tahun sebanyak 42,5 \%. Usia 30-34 tahun termasuk dalam kategori dewasa awal yang berhubungan dengan kebijaksanaan dan kesabaran dalam caring terhadap pasien. Karakteristik pendidikan paling banyak adalah D3 keperawatan sebanyak 93,2\% sedangkan S1 keperawatan 6,8 \%. Karakteristik masa kerja Responden terbanyak adalah antara 1-5 tahun sebanyak 35,6 \%. Hal ini menunjukkan bahwa perawat wanita yang bekerja di RS Ananda sebagian besar tergolong masih baru.. Status kepegawaian responden yang paling banyak adalah berstatus pegawai sebanyak 82,2 \% sisanya masih honorer sebanyak 17,8 \%. Respoden yang mempunyai jumlah anak dua merupakan yang terbanyak sebanyak $49,6 \%$.

b. Hasil Uji Instrumen

a) Uji Validasi 
Uji validitas bertujuan untuk mengetahui kevalidan sebuah kuesioner yang akan digunakan dalam penelitian. Dasar pengambilan keputuan uji validitas jika rhitung< rtabel pada nilai signifikan 5\% dikatakan tidak valid. Uji coba kuesioner dilakukan untuk mengetahui tingkat kevalidan. Pada semua pernyataan kuesioner didapatkan hasil bahwa rhitung > rtabel pada nilai signifikan 5\%. Dengan demikian dapat disimpulkan bahwa semua item pernyataan variabel valid. b) Uji Reliabilitas

Uji reliabilitas digunakan untuk mengukur konsistensi dari suatu variabel yang akan digunakan dalam penelitian. Butir pertanyaan dalam variabel dikatakan reliabel atau terpercaya apabila jawaban responden adalah konsisten atau stabil dari waktu ke waktu. Suatu variabel dikatakan reliabel jika nilai Cronbach's Alpha $(\geq$ $0,60)>$ rtabel, begitu sebaliknya apabila nilai Cronbach's Alpha $(\geq$ $0,60)<$ rtabel dikatakan tidak reliabel.

Tabel 2

Hasil Uji Reliabilitas

\begin{tabular}{|c|c|c|c|}
\hline Variabel & Cronbach's Alpha & $\mathbf{r}_{\text {tabel }} 5 \%(30)$ & Keterangan \\
\hline $\begin{array}{l}\text { Konflik } \\
\text { Pekerjaan }\end{array}$ & 0,942 & 0,361 & Reliabel \\
\hline Burnout & 0,967 & 0,361 & Reliabel \\
\hline Stres Kerja & 0,940 & 0,361 & Reliabel \\
\hline Perilaku Caring Perawat & 0,947 & 0,361 & Reliabel \\
\hline
\end{tabular}

Sumber: Hasil Analisis Reliabilitas, 2020

Berdasarkan tabel 2, dapat disimpulkan bahwa semua variabel reliabel atau konsisten karena nilai Cronbach's Alpha > rtabel. Sehingga dapat digunakan sebagai instrumen dalam penelitian.

c. Uji Deskripsi Statistik

a) Analisis Univariat

Analisis angka indeks ini dilakukan untuk mengetahui persepsi umum responden mengenai sebuah variabel yang diteliti yaitu konflik keluarga-pekerjaan, burnout, stres kerja dan perilaku caring perawat. Analisis data dapat dilakukan untuk menyajikan temuan emperis berupa data statistik deskriptif yang menjelaskan mengenai karakteristik responden khususnya dalam hubungannya dengan variabelvariabel penelitian yang digunakan dalam pengujian hipotesis. Untuk mendapatkan kecenderungan jawaban responden terhadap masing-masing variabel, maka akan didasarkan pada nilai skor rata-rata dari hasil perhitungan Three Box Method (Bachriansyah \& Ferdinand, 2011).

d. Three Box Method

Teknik skoring yang digunakan dalam penelitian ini adalah dengan skor maksimal 4 dan minimal 1, sedangkan jenis statistik yang disajikan adalah angka indeks.

Rumus Three Box Method

a. Batas atas rentang skor: $(\% \mathrm{Fx} 4) / 5$

b. Batas bawah rentang skor: $(\% \mathrm{Fx} 1) / 5$

Maka perhitungan indeks jawaban responden dengan rumus berikut:

Nilai indeks $=((\% \mathrm{~F} 1 \times 1) / 5+(\% \mathrm{~F} 2 \times 2) / 5+$ $(\% \mathrm{~F} 3 \times 3) / 5+(\% \mathrm{~F} 4 \times 4) / 5$.

e. Matriks Tanggapan Responden

Berdasarkan hasil deskripsi jawaban responden terhadap variabel perilaku caring perawat, konflik keluarga- 
pekerjaan, burnout, dan stres kerja, dapat pada tabel 3 sebagai berikut: digambarkan kedalam metriks perilaku

Tabel 3

Matriks Tanggapan Responden

\begin{tabular}{lccl}
\hline \multirow{2}{*}{ Variabel } & \multicolumn{2}{c}{ Posisi Tanggapan } & \multicolumn{1}{c}{ Keterangan } \\
\cline { 2 - 4 } & Responden & \\
\hline Perilaku caring Perawat & Sedang Tinggi & $\begin{array}{l}\text { Responden mempunyai } \\
\text { perilaku caring yang } \\
\text { baik. }\end{array}$ \\
\hline $\begin{array}{l}\text { Konflik } \\
\text { Pekerjaan }\end{array}$ & Keluarga- & $*$ & $\begin{array}{l}\text { Responden mempunyai } \\
\text { tingkat konflik yang } \\
\text { sedang. }\end{array}$ \\
\hline Burnout & $* \begin{array}{l}\text { Responden mempunyai } \\
\text { tingkat burnout yang } \\
\text { tinggi }\end{array}$ \\
\hline Stres Kerja & $*$ & $\begin{array}{l}\text { Responden mengalami } \\
\text { tingkat stres kerja } \\
\text { sedang, }\end{array}$ \\
\hline
\end{tabular}

a) Analisis bivariat bertujuan untuk mengetahui tingkat keeratan hubungan antar variabel yang dinyatakan dengan koefisiensi korelasi (r). Sedangkan dasar pengambilan keputusan uji korelasi adalah:

a. Jika Pvalue $<0,05$, maka artinya ada korelasi

b. Jika Pvalue $>0,05$, maka tidak ada korelasi

Didapatkan bahwa Pvalue 0,000 dan nilai $r$ positif. Hasil ini berarti nilai $p$ lebih kecil dari $\alpha(0,05)$ maka dengan demikian dapat dikatakan bahwa semua item pernyataan variabel perilaku caring perawat ada korelasi antara masing-masing item pertanyaan

\section{i Korelasi}

Uji korelasi pearson bertujuan untuk mengetahui tingkat keeratan hubungan antar variabel yang dinyatakan dengan koefisiensi korelasi (r). Jenis hubungan antar variabel independen dan dependen dapat bersifat positif atau negatif. Dasar pengambilan keputusan uji korelasi adalah:

a) Jika Pvalue $<0,05$, maka artinya ada korelasi.

b) Jika Pvalue > 0,05, maka tidak ada korelasi.

Tabel 4

Uji Korelasi Antar Variabel

\begin{tabular}{lccc}
\hline Variabel & N & Nilai Sig & Pearson Correlation \\
\hline \hline $\begin{array}{l}\text { Konflik keluarga-pekerjaan dan } \\
\text { Stres Kerja }\end{array}$ & 73 & 0,000 & 0,609 \\
\hline $\begin{array}{l}\text { Konflik keluarga-pekerjaan dan } \\
\text { burnout }\end{array}$ & 73 & 0,000 & 0,705 \\
\hline Konflik keluarga-pekerjaan dan & 73 & 0,004 & $-0,334$ \\
\hline
\end{tabular}


Mahmuddin, Rokiyah Kusumapradja, Idrus Jus'at

\begin{tabular}{llll}
\hline Perilaku Caring Perawat & & \\
\hline $\begin{array}{l}\text { Stres Kerja dan Perilaku Caring } \\
\text { Perawat }\end{array}$ & 73 & 0,000 & $-0,650$ \\
\hline $\begin{array}{l}\text { Burnout dan Perilaku Caring } \\
\text { Perawat }\end{array}$ & 73 & 0,000 & $-0,621$ \\
\hline
\end{tabular}

Berdasarkan tabel 4 dapat disimpulkan bahwa:

1. Konflik keluarga-pekerjaan dan stres kerja. $\mathrm{P}_{\text {value }} 0,000<0,05$, dan nilai $\mathrm{r}$ 0,609 , terdapat hubungan antara konflik keluarga-pekerjaan dengan stres kerja.

2. Konflik keluarga-pekerjaan dan burnout. $\mathrm{P}_{\text {value }} 0,000<0,05$ dan nilai $\mathrm{r}$ 0,705 , terdapat hubungan antara konflik keluarga-pekerjaan dengan burnout.

3. Konflik keluarga-pekerjaan dan Perilaku Caring Perawat. $\mathrm{P}_{\text {value }} 0,004<$ 0,05 dan nilai $r \quad-0,334$, terdapat hubungan antara konflik keluargapekerjaan derngan perilaku caring perawat.

4. Stres kerja dan perilaku caring perawat. $\mathrm{P}_{\text {value }} 0,000<0,05$ dan nilai $\mathrm{r}-0,650$, artinya terdapat hubungan antara stres kerja dengan perilaku caring perawat.
5. Burnout dan perilaku caring perawat. $\mathrm{P}_{\text {value }} 0,000<0,05$ dan nilai $\mathrm{r}-0,621$, terdapat hubungan antara burnout dengan perilaku caring perawat.

\section{g. Analisis Regresi Linear Berganda}

a) Uji Normalitas

Uji normalitas digunakan untuk menguji apakah data yang bersangkutan berdistribusi normal atau tidak. Uji normalitas dapat dilakukan dengan menggunakan uji KolmogorovSmirnov. Dasar pengambilan keputusan apabila nilai signifikasi > 0,05 maka nilai residual berdistribusi normal dan apabila nilai signifikasi $<_{s} 0,05$ maka nilai residual tidak berdistribusi normal.

Hasil uji normalitas dapat dilihat pada tabel berikut:

Tabel 5

Hasil Uji Normalitas

\begin{tabular}{l|c|c}
\hline \multicolumn{1}{c|}{ Variabel } & Nilai $\boldsymbol{\alpha}$ & Nilai Sig. \\
\hline Konflik Keluarga-Pekerjaan & 0,05 & 0,064 \\
\hline Burnout & 0,05 & 0,056 \\
\hline Stres Kerja & 0,05 & 0,200 \\
\hline
\end{tabular}

Berdasarkan hasil uji normalitas tabel

5 dapat disimpulkan bahwa:

1. Variabel konflik keluargapekerjaan diketahui nilai sig $0,064>0,05$ maka dapat disimpulkan bahwa residual berdistribusi normal.

2. variabel burnout diketahui nilai signifikan $0,056>0,05$ maka dapat disimpulkan bahwa residual berdistribusi normal.
3. variabel stres kerja diketahui nilai signifikan $0,200>0,05$ maka dapat disimpulkan bahwa residual berdistribusi normal.

Menurut Ghozali (2013), model regresi dikatakan berdistribusi normal jika ploting (titik - titik) yang menggambarkan data sesungguhnya. 




Dari gambar 1 dapat disimpulkan bahwa dari hasil uji normalitas terlihat titik-titik mengikuti garis sehingga dapat dikatakan berdistribusi normal.

Sedangkan dilihat dari histogram uji normalitas, data yang berdistribusi normal adalah data yang histogramnya berada tidak jauh dari kurva normal yang berbentuk lonceng pada grafik histogram diatas dapat dilihat bahwa dari interval pertama sampai yang terakhir tidak jauh dari kurva normal seperti yang terlihat pada gambar dibawah ini.

Dan jika grafik histogram uji normalitas jika terdapat bahwa kurva dependent dan regression standardized residual mebuntuk gambar seperti lonceng, jadi ini membuktikan bahwa uji normalitas.

\section{b) Uji Multikolinearitas}

Uji multikolinearitas bertujuan untuk menguji apakah pada model regresi ditemukan adanya korelasi antar variabel independen atau tidak. Jika terjadi korelasi, maka terdapat masalah Multikolinearitas. Model regresi yang baik seharusnya tidak terjadi korelasi di antara variabel independen. Deteksi tidak adanya Multikolinearitas yakni dengan melihat besaran nilai (Variance Inflation Factor) dan nilai Toleran.

Tabel 5

Hasil Uji Multikolinearitas

\section{Coefficientsa}

\begin{tabular}{|c|c|c|c|c|c|c|c|}
\hline \multirow[b]{2}{*}{$\underline{\text { Model }}$} & \multicolumn{2}{|c|}{$\begin{array}{l}\text { Unstandardized } \\
\text { Coefficients }\end{array}$} & \multicolumn{2}{|c|}{$\begin{array}{l}\text { Standardizec } \\
\text { Coefficients }\end{array}$} & \multirow[b]{2}{*}{ Sig. } & \multirow{2}{*}{\multicolumn{2}{|c|}{$\begin{array}{l}\text { Collinearity } \\
\text { Statistics } \\
\end{array}$}} \\
\hline & $\overline{\mathbf{B}}$ & Std. Error & Beta & $\mathbf{t}$ & & & (VIF \\
\hline 1 (Constant) & 11,186 & 2,486 & & 4,500 & ,000 & & \\
\hline Konflik (X1) &,- 174 & ,069 &,- 306 & $-2,532$ & 014 & 481 & 2,080 \\
\hline Burnout (X2) & ,378 & ,107 & ,488 & $-3,542$ & ,001 & ,369 & 2,710 \\
\hline Stres Kerja (X3) & ,275 & ,070 & ,485 & $-3,938$ & ,000 & ,462 & 2,164 \\
\hline
\end{tabular}

Menurut Ghozali (2013), tidak terjadi gejala multikolinearitas, jika nilai toleran > 0,100 dan nilai VIF < 10,00 .
Berdasarkan tabel diatas dapat disimpulkan bahwa:

1. Konflik Keluarga-Pekerjaan 0,481 > 0,100 dan $2,080<10,00$ 
2. Burnout $0,369>0,100$ dan $2,710<$ 10,00

3. Stres Kerja 0,462>0,100 dan 2,164 $<10,00$

Dengan melihat nilai toleransi dan nilai VIF dari tabel diatas maka dapat disimpulkan bahwa semua variabel independen tidak terjadi Multikolinearitas.

\section{Uji T}

Uji T dikenal dengan uji parsial, yaitu untuk menguji bagaimana pengaruh masingmasing variabel independen secara sendirisendiri terhadap variabel dependen. Uji ini dapat dilakukan dengan mambandingkan Thitung dengan $\mathrm{T}$ tabel atau dengan melihat kolom signifikansi pada masing-masing
Thitung. Dengan tingkat kepercayaan $95 \%, \alpha$ 0,05 (standar statistik).

Menurut (Ghozali, 2018), jika Pvalue < 0,05 maka artinya variabel independen secara parsial berpengaruh terhadap variabel dependen, dan jika Pvalue > 0,05 maka artinya variabel independen secara parsial tidak berpengaruh terhadap variabel dependen. Dan Uji t parsial berdasarkan nilai Thitung dan Ttable.

Jika nilai thitung > ttabel, artinya variabel independen secara parsial berpengaruh terhadap variabel dependen, dan jika thitung < ttabel, maka tidak terdapat pengaruh variabel independen terhadap variabel dependen dalam hal ini bisa berpengaruh secara positif atau negatif

Tabel 7

Hasil Uji t parsial

\begin{tabular}{|c|c|c|c|c|c|c|c|}
\hline \multirow[b]{3}{*}{ Model } & \multicolumn{5}{|c|}{ Coefficientsa } & & \\
\hline & \multicolumn{2}{|c|}{$\begin{array}{l}\text { Unstandardized } \\
\text { Coefficients }\end{array}$} & \multirow{2}{*}{$\begin{array}{c}\text { Standardized } \\
\text { Coefficients } \\
\text { Beta }\end{array}$} & \multirow[t]{2}{*}{$\mathbf{t}$} & \multirow[t]{2}{*}{ Sig. } & \multicolumn{2}{|c|}{$\begin{array}{c}\text { Collinearity } \\
\text { Statistics }\end{array}$} \\
\hline & $\mathbf{B}$ & Std. Error & & & & Tolerance & VIF \\
\hline$\overline{1(\text { Constant })}$ & 11,186 & 2,486 & & 4,500 &, 000 & & \\
\hline Konflik (X1) &,- 174 &, 069 &,- 306 & $-2,532$ &, 014 & ,481 & 2,080 \\
\hline Burnout (X2) & ,378 &, 107 &, 488 & $-3,542$ &, 001 & ,369 & 2,710 \\
\hline Stres Kerja (X3) & 275 &, 070 &, 485 & $-3,938$ &, 000 & ,462 & 2,164 \\
\hline
\end{tabular}

a. Dependent Variable: Caring (Y)

Berdasarkan tabel 7 dapat disimpulkan bahwa:

a. Hipotesis 1

Variabel konflik keluarga-pekerjaan (X1) adalah $\mathrm{P}_{\text {value }} 0,014<0,05$ dan nilai $\mathrm{t}$ hitung $-2,532>\mathrm{t}$ tabel 1,994 , sehingga dapat disimpulkan bahwa H1 diterima. Konflik keluarga-pekerjaan berpengaruh secara negatif dan signifikan terhadap perilaku caring perawat, yang artinya semakin tinggi konflik maka semakin menurun perilaku caring perawat.

b. Hipotesis 2

Variabel burnout adalah $\mathrm{P}_{\text {value }} 0,001$ $<0,05$ dan nilai $\mathrm{t}$ hitung $-3,542>1,994$, sehingga dapat disimpulkan $\mathrm{H} 2$ diterima.
Ada pengaruh burnout berpengaruh secara negatif dan signifikan terhadap perilaku caring perawat. yang artinya semakin meningkat burnout maka semakin menurun perilaku caring perawat.

c. Hipotesis 3

Diketahui nilai Sig stres kerja (X3) adalah sebesar $0,000<0,05$ dan nilai $\mathrm{t}$ hitung $-3,938>\mathrm{t}$ tabel 1,994, sehingga dapat disimpulkan bahwa $\mathrm{H} 3$ diterima. Stres kerja berpengaruh secara negatif dan signifikan terhadap perilaku caring perawat, yang artinya semakin meningkat stress kerja maka semakin menurun perilaku caring perawat. 


\section{Uji F}

Uji $F$ dikenal dengan Uji simultan (bersama-sama). Uji F untuk melihat pengaruh variabel independen secara bersama-sama terhadap variabel dependen. Jika model signifikan maka model bisa digunakan untuk prediksi/peramalan, sebaliknya jika tidak signifikan maka model tidak bisa digunakan untuk peramalan.

Menurut ghozali (2013), jika Pvalue < 0,05 artinya variabel independen secara simultan berpengaruh terhadap variable dependen. Dan uji $F$ berdasarkan nilai Fhitung dan Ftabel,

Jika nilai Fhitung > Ftabel, maka artinya variabel independen secara simultan berpengaruh terhadap variabel dependen begitu juga sebaliknya jika jika Pvalue $>0,05$ artinya variabel independen secara simultan tidak berpengaruh terhadap variabel dependen. Dan uji $F$ berdasarkan nilai Fhitung dan Ftabel. Jika nilai Fhitung < Ftabel, maka artinya variabel independen secara simultan tidak berpengaruh terhadap variabel dependen.

\section{Tabel 8}

Uji F

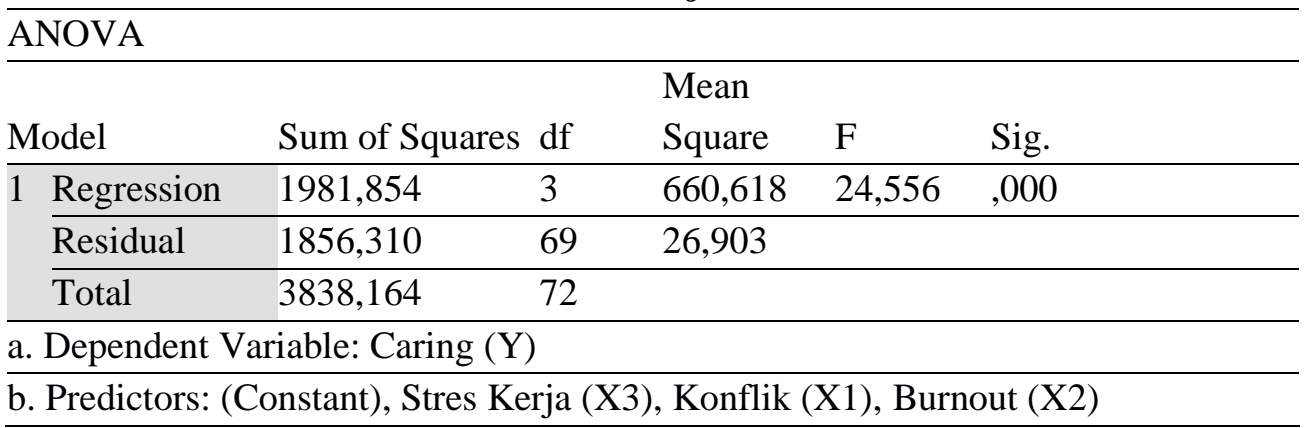

Berdasarkan tabel 8 uji $F$ dapat disimpulkan bahwa Pvalue 0,000 $<0,05$ dan nilai $\mathrm{F}$ hitung 24,556 > 2,74 (F tabel), artinya hipotesis 4: diterima. Yang artinya konflik keluarga-pekerjaan, burnout dan stres kerja berpengaruh secara positif dan signifikan terhadap perilaku caring perawat.

\section{Pembahasan Hipotesis}

1. H1: Terdapat pengaruh konflik keluargapekerjaan secara negatif dan signifikan terhadap perilaku caring perawat

Terdapat pengaruh antara konflik keluarga-pekerjaan secara negatif terhadap perilaku caring perawat, yang artinya semakin tinggi konflik keluarga-pekerjaan pada perawat wanita yang sudah berkeluarga maka semakin menurun perilaku caring perawat.

Hal ini mendukung dari teori (Gutek et al., 1991), menyebutkan bahwa konflik keluarga- pekerjaan yaitu urusan keluarga mengganggu pekerjaan, seperti anak yang sedang sakit akan menghalangi seseorang karyawan untuk datang ke tempat kerja atau terlambat masuk kerja). Perawat wanita yang telah menikah dan punya anak memiliki peran dan tanggung jawab yang lebih berat dari pada perawat wanita yang masih lajang. Peran ganda pun dialami oleh perawat wanita tersebut karena selain berperan di dalam keluarga, perawat wanita tersebut juga berperan di dalam karirnya. Konflik keluarga-pekerjaan mengacu pada suatu konflik antar peran dimana tuntutan umum, waktu, dan ketegangan yang diciptakan oleh pekerjaan. Hasil penelitian ini sejalan dengan penelitian (Safaat, 2018), yang menyebutkan ada hubungan konflik keluarga-pekerjaan dan pekerjaan-keluarga dengan perilaku caring perawat wanita di 
ruang perawatan RSUD Batara Guru Kabupaten Luwu.

2. H2: Terdapat pengaruh burnout secara negatif dan signifikan terhadap perilaku caring perawat.

Menurut penelitian (Maslach et al., 2001) menggambarkan individu dengan status belum menikah memiliki tingkat burnout yang lebih tinggi dibandingkan dengan individu yang berstatus menikah, hal ini disebabkan adanya pasangan hidup akan memberikan dukungan emosional pada pasangannya saat adanya masalah. Burnout timbul apabila kelelahan berlangsung cukup lama dan secara terus menerus dapat menguras sumber energi.

Hasil penelitian ini berbeda dengan penelitian (Talenta \& Wardani, 2018), dimana hasil penelitian pada 87 perawat di RS Kanker menunjukkan tidak adanya hubungan bermakna antara tingkat burnout dengan perilaku caring perawat onkologi di RS Kanker Jakarta.

Kelelahan adalah fenomena umum yang terjadi pada berbagai tipe pekerjaan, dan setiap jenis pekerjaan mempunyai karakteristik kelelahan kerja tersendiri (Yogisutanti et al., 2018). Faktor-faktor yang dapat berpengaruh terhadap terjadinya kelelahan kerja, bermacammacam, mulai dari faktor lingkungan kerja yang tidak memadai untuk bekerja sampai kepada masalah psikososial.

Menurut (Prestiana \& Purbandini, 2012), publikasi mengenai tentang kelelahan pekerja di eropa menunjukkan 4\% kelelahan kerja dialami pekerja hukum dan kepolisian, 9\% dialami pekerja administrasi dan manajemen, $32 \%$ dialami guru, dan kesehatan (khususnya perawat) adalah peringkat pertama pekerja yang mudah mengalami kelelahan kerja dibanding dokter dan apoteker (Eviaty \& Setiadarma, 2005). Dari jumlah pasien yang banyak berpengaruh juga pada pekerjaan perawat, kegiatan pelayanan keperawatan agar mencapai kualitas yang optimal yaitu apabila beban kerja dan sumber daya perawat yang ada memilki proporsi yang seimbang dengan jumlah yang ada. (Wulandari et al., 2021). Menurut Susanto dalam (Ambarwati, 2007) tuntutan-tuntutan melebihi kapasitas dari seorang perawat dengan tuntutan yang terlalu banyak akan mengalami kelelahan. Dampak negatif dari meningkatnya beban kerja adalah kemungkinan timbul emosi perawat yang tidak sesuai dengan harapan pasien. Beban kerja yang belebihan ini sangat berpengaruh terhadap produktifitas tenaga kesehatan yang berpengaruh pada produktifitas rumah sakit.

3. H3: Terdapat pengaruh stres kerja secara negatif dan signifikan terhadap perilaku caring perawat. Artinya secara parsial stres kerja berpengaruh secara negatif terhadap perilaku caring perawat, yang artinya semakin meningkat stres kerja maka semakin perilaku caring perawat.

Menurut (Potter, 2010) menyatakan bahwa perawat yang tidak mampu menghilangkan stres akan berdampak pada menurunnya penampilan kerja dan memburuknya pelayanan terhadap pasien. Dalam pelayanan kesehatan, perawat yang mengalami stres berat akan mengalami kejenuhan dan kehilangan motivasi dalam bekerja. Caring merupakan perwujudan dari semua faktor yang digunakan perawat dalam memberikan pelayanan kesehatan pada klien. Hasil penelitian ini sejalan dengan penelitian (Desima, 2013). perawat yang yang bekerja di ruang rawat inap sering kali mengalami stres akan mengalami kehilangan motivasi, kejenuhan yang berat dan tidak masuk kerja lebih sering, sehingga ini akan berdampak pada penurunan kualitas kerja terutama terhadap perilaku caring yang ditunjukkan oleh perawat terhadap pasien, khususnya bagi perawat yang berada di Instalasi Rawat Inap yang menghadapi berbagai macam 
keluhan pasien. Ada hubungan antara tingkat stres kerja dengan perilaku caring perawat Di Istalansi Rawat Inap Rumah Sakit Islam Malang. Dengan demikian tingkat stres kerja perawat mempengaruhi perilaku caring perawat.

4. H4: Terdapat pengaruh signifikan antara konflik keluarga-pekerjaan, kelelahan kerja dan stres kerja terhadap perilaku caring perawat.

Dari hasil olah data uji $\mathrm{F}$, didapatkan $\mathrm{P}_{\text {value }} 0,000<0,05$ dan nilai $\mathrm{F}$ hitung $7,752>2,74\left(\mathrm{~F}_{\text {tabel }}\right)$, artinya konflik keluarga-pekerjaan, burnout dan stres kerja secara simultan berpengaruh terhadap perilaku caring perawat. Perilaku caring perawat yang rendah disebabkan dari banyaknya masalah yang dihadapi oleh perawat baik itu masalah keluarga, stres ditempat kerja dan kelelahan kerja. Work-family conflict dapat mengarah terhadap stres kerja karena banyaknya waktu yang dibutuhkan untuk menangani segala urusan pekerjaan sehingga hal tersebut merupakan sumber potensial terjadinya stres kerja (Judge et al., 1994). Konflik peran yang terjadi antara peran keluaga dan pekerjaan yang dialami wanita yang bekerja dapat menimbulkan ketegangan yang dapat menimbulkan stres kerja. Pada satu sisi wanita diharuskan menjalankan perannya dalam keluarga tetapi kadangkala wanita harus menyelesaikan pekerjaannya sehingga harus membawa pekerjaannya kerumah yang mana hal tersebut dapat mengganggu perannya dalam keluarga. Ketegangan antar peran tersebut dapat menyebabkan munculnya stres kerja pada wanita yang bekerja karena perannya yang tidak dijalankan dengan seimbang sehingga akan menyebabkan terjanya kelelahan kerja dan akhirnya akan berpengaruh pada perilaku caring perawat yang buruk. Untuk itu diperlukan langkah-langkah pencegahan untuk mencegah perlaku caring semakin buruk.

\section{Kesimpulan}

Dari hasil penelitian ini, ada beberapa hal yang penulis simpulkan, antara lain ada pengaruh antara konflik keluarga-pekerjaan dengan perilaku caring perawat secara negatif dan signifikan. Artinya semakin tinggi konflik semakin menurun perilaku caring perawat.

Ada pengaruh antara burnout dengan perilaku caring perawat secara negatif dan signifikan. Artinya semakin meningkat burnout semakin menurun perilaku caring perawat.

Ada pengaruh antara stres kerja dengan perilaku caring perawat secara negatif dan signifikan. Artinya semakin meningkat stress kerja semakin menurun perilaku caring perawat.

Secara simultan konflik keluargapekerjaan, burnout dan stres kerja berpengaruh positif dan signifikan terhadap perilaku caring perawat. Artinya secara bersama-sama konflik keluarga-pekerjaan, burnout dan stres kerja meningkat semakin tinggi perilaku caring perawat.

\section{BIBLIOGRAFI}

Ambarwati, W. (2007). Study On The English Teaching Techniques At The First Grade Of Smu Alislam Krian. University Of Muhammadiyah Malang. Google Scholar

Bachriansyah, R. A., \& Ferdinand, A. T. (2011). “Analisis Pengaruh Kualitas Produk, Daya Tarik Iklan, Dan Persepsi Harga Terhadap Minat Beli Konsumen Pada Produk Ponsel Nokia (Studi Kasus Pada Masyarakat Di Kota Semarang). Universitas Diponegoro. Google Scholar

Desima, R. (2013). Tingkat Stres Kerja Perawat Dengan Perilaku Caring Perawat. Jurnal Keperawatan, 4(1). 
Mahmuddin, Rokiyah Kusumapradja, Idrus Jus'at

Google Scholar

Eviaty \& Setiadarma, M. P. (2005). Persepsi Terhadap Dukungan Rekan Sekerja Dan Gejala Burnout (Studi Pada Perawat Unit Perawatan Intensif). Jurnal Phronesis, 7(2). Google Scholar

Ghozali, I. (2018). Aplikasi Analisis Multivariate Dengan Program Ibm Spss 25. Google Scholar

Gutek, B. A., Searle, S., \& Klepa, L. (1991). Rational Versus Gender Role Explanations For Work-Family Conflict. Journal Of Applied Psychology, 76(4), 560. Google Scholar

Judge, T. A., Boudreau, J. W., \& Bretz, R. D. (1994). Job And Life Attitudes Of Male Executives. Journal of Applied Psychology, 79(5), 767. Google Scholar

Maslach, C., Schaufeli, W. B., \& Leiter, M. P. (2001). Job Burnout. Annual Review Of Psychology, 52(1), 397-422. Google Scholar

Phillips, P. (1993). A Deconstruction Of Caring. Journal Of Advanced Nursing, 18(10), 1554-1558. Google Scholar

Potter, W. J. (2010). The State Of Media Literacy. Journal of Broadcasting \& Electronic Media, 54(4), 675-696. Google Scholar
Prestiana, N. D. I., \& Purbandini, D. (2012). Hubungan Antara Efikasi Diri (Self Efficacy) Dan Stres Kerja Dengan Kejenuhan Kerja (Burnout) Pada Perawat Igd Dan Icu Rsud Kota Bekasi. Soul: Jurnal Pemikiran Dan Penelitian Psikologi, 5(2), 1-14. Google Scholar

Safaat, H. (2018). Hubungan Konflik Peran Ganda Dan Beban Kerja Dengan Perilaku Caring Perawat Di Ruang Rawat Inap Rsud Batara Guru Belopa Kabupaten Luwu Provinsi Sulawesi Selatan Tahun 2016. Jurnal Fenomena Kesehatan, 1(1), 63-76. Google Scholar

Talenta, C., \& Wardani, I. Y. (2018). Burnout Dan Perilaku Caring Perawat Onkologi. Jurnal Keperawatan, 10(3), 201-208. Google Scholar

Wulandari, A., Aviantono, B., \& Parantoro, A. (2021). Model Persamaan Struktural: Peran Kepemimpinan Transformasional Menuju Kinerja Karyawan Dan Keterikatan Karyawan. Value: Jurnal Manajemen Dan Akuntansi, 16(1), 1423. Google Scholar

Yogisutanti, G., Ardayani, T., \& Simangunsong, D. S. U. (2018). Pengaruh Senam Tai Chi Terhadap Fleksibilitas Dan Kekuatan Otot Ekstremitas Pada Lansia Di Gereja Bandung Barat. Journal of Public Health Research And Community Health Development, 2(1), 60-68. Google Scholar

\section{Copyright holder:}

Mahmuddin, Rokiyah Kusumapradja, Idrus Jus'at (2022)

\section{First publication right:}

Jurnal Health Sains

This article is licensed under: 